\title{
GUCY1A1 wt Allele
}

National Cancer Institute

\section{Source}

National Cancer Institute. GUCY1A1 wt Allele. NCI Thesaurus. Code C52037.

Human GUCY1A1 wild-type allele is located in the vicinity of 4q32.1 and is approximately $70 \mathrm{~kb}$ in length. This allele, which encodes guanylate cyclase soluble subunit alpha-1 protein, plays a role in both the biosynthesis of cyclic GMP and binding of nitric oxide. Mutation of the gene is associated with moyamoya 6 with achalasia. 